\title{
아동기 정서적 외상과 역기능적 분노표현과의 관계: 단절 및 거절도식과 심리적 부적응의 매개효과
}

본 연구는 아동기 정서적 외상, 단절 및 거절도식 및 심리적 부적응이 역기능적 분노표현에 어떤 영향을 미치 는지를 구조방정식 모형을 통해 검증하고자 하였다. 연구대상은 서울과 경기, 인천지역 대학생 341명이었고 자 료처리는 정서적 외상, 단절 및 거절도식, 심리적 부적응, 역기능적 분노표현간의 상관분석을 하고, 이들 변인들 의 관계의 구조를 파악하기 위해 구조방정식 모형검증을 실시하였다. 연구 결과는 아동기 정서적 외상이 단절 및 거절도식에 영향을 주고 단절 및 거절도식이 심리적 부적응에 영향을 주어 다시 심리적 부적응이 역기능적 분노표현에 차례로 영향을 미치는 모형의 적합도가 더 높게 나왔다. 이상의 결과를 바탕으로, 아동기 정서적 외 상과 역기능적인 분노표현의 관계에서 매개변인인 단절 및 거절도식과 심리적 부적응을 다룸으로써, 분노에 대 한 치료적 개입 방향을 다양화할 수 있다는 점을 논의 하였다. 마지막으로 본 연구에서의 의의 및 제한점, 향후 연구방향에 대해 논의 하였다. 


\section{I. 서론}

우리가 일상적으로 흔히 경험하는 정서인 분노는 인간의 옥구가 좌절될 때 경험하게 되는 인 간의 중요하고도 보편적인 감정중의 하나이다(전현숙, 손정락, 2011), 우리나라 성인들을 대상으 로 한 분노에 관한 예비연구에 의하면 참여자의 절반이 적어도 일주일 동안에 1 2번 분노를 경험한다고 하였고 일주일에 3 5번 분노를 경험한다고 한 사람들도 $25 \%$ 를 넘는다고 보고하였 다(전겸구, 1999). 분노는 일반적으로 불쾌하고 부정적인 감정으로 여겨지지만, 분노에는 기능적 이고 긍정적인 특성 또한 존재한다(Bilodeau, 1992). 분노는 우리가 정해놓은 경계가 침범 당했 거나, 마음의 상처를 입었거나 권리를 침해당했거나 소망이나 욕구가 충족되지 않았거나 혹은 목표를 향한 진행이 좌절되고 있음을 알려주는 메시지이므로(Greenberg, 2001) 분노를 적절히 조절하는 것은 적응적인 삶에서 필수적인 조건이라고 할 수 있다. 하지만 분노관련 문제를 가진 사람들은 분노를 과잉으로 통제하거나 극단적으로 표출함으로써 개인의 신체적 및 심리적 건강 을 해칠 뿐만 아니라 타인과의 인간관계나 직업 생활에 부정적인 영향을 미치기 쉽다(서수균, 2004).

분노와 관련된 연구에서 가장 널리 쓰이는 개념적 분류는 Spielberger, Reheiser, 와 Sydman(1995)에 의한 것으로 분노표현 행동을 분노표출(anger-out), 분노억압(anger-in), 분노조 절(anger-control)의 세 가지로 구분하였다. 분노표출은 화가 나면 이를 겉으로 드러내는 것으로 화난 표정을 지어보인다거나 욕하는 것, 말다툼이나 과격한 공격행동을 보이는 것 등이 그 예다. 분노억제는 화가 나 있지만 이를 겉으로 드러내지 않는 것으로 화가 나면 오히려 말을 하지 않 거나 사람을 피하고 속으로만 상대방을 비판하는 경우가 이에 해당된다. 이에 비해 분노조절은 분노를 경험하고 있는 스스로의 상태에 대해 자각하는 것으로 감정을 진정시키기 위해 여러 가 지 책략을 구사하고 상대방을 이해하기 위해 노력하는 것이다. 일반적으로 분노조절은 기능적인 방식으로 여겨지고 분노표출과 분노억압은 역기능적인 분노표현 방식으로 구분되어져 왔다 (Bilodeau, 1992; Gottlieb, 1999). 역기능적인 분노표현은 고혈압을 비롯한 심혈관계 질환, 통증 민감성, 면역체계저하 등 신체적 건강에 부정적인 영향을 미치기도 한다(전겸구, 한덕웅, 이장 호, Spielberger, 1997에서 재인용). 또한 강박관념, 편집증적 성격, 감정조절의 어려움, 화병 등을 비롯한 정서적 부적응을 초래할 수 있으며, 더 나아가 공격성이 표현되기도 하고, 대인관계의 어려움, 사회적 문제가 되는 반사회적인 성향이 표출되고 인격장애로 발전되기도 한다(조한익, 최종환, 2013에서 재인용).

한편, 우리나라에서 2013년 발표된 아동학대 통계자료에 의하면 아동학대로 신고 된 건수는 2002년 2,218 건에서 2012년 9,938건으로 4배 이상 증가해 왔고, 2002년 전체의 $9 \%$ 를 차지했던 정서학대는 2012년 38\%로 가장 높은 비중을 차지하게 되었다(아동보호전문기관, 2013). 증가하 
는 아동학대 통계자료와 관련하여, Bowlby의 애착이론에 근거한 애착 연구자들에 따르면 아동 기의 가족관계 특히, 애착 대상인 부모와의 관계에서 경험한 학대와 방임은 아동기 뿐 아니라 청소년기 및 성인기에까지 한 개인의 성격 발달과 정서행동 조절문제들에 심각한 악영향을 미 친다고 한다(Allen, 2005; Bowlby, 1980; Mullen, Martin, Anderson, Romans, \& Herbison, 1996). 또한, 외관상 뚜렷한 징후를 보이는 신체적 학대와 별개로 정서적 학대만으로도 장기적인 심리적 기능의 손상에 영향을 미칠 수 있으며 신체적 학대보다 정서적 학대가 오히려 아동의 정상적인 발달에 치명적이라는 연구결과들이 발표되었다(Egeland, 2009; Wright, Crawford, \& Castillo, 2009). 즉, 정서적 외상인 정서적 학대와 방임은 아동의 내면에 불안, 좌절감, 분노를 유발한다고 하며, 아동의 행동적, 정서적 부적응 문제를 야기하는 주요한 원인이 되며, 성장 후 에도 성인기 정신병리를 포함한 여러 심리적 문제와 연관된다(Allen, 2001; Schore, 2001; Spettus, Yehuda, Wong, Halligan, \& Seremetis, 2003). 또한 최근 연구에 의하면 만성적인 분 노와 역기능적인 분노표현은 아동기 정서적 외상의 결과라는 주장(이지영, 손정락, 2010; 조한익, 최종환, 2013)이 지지되고 있는 바 본 연구에서는 아동기의 정서적 외상경험이 어떠한 과정을 거쳐서 역기능적인 분노표현에 영향을 미치는지 그 관계를 살펴보면서 이를 매개하는 심리적 변인들을 알아보는 것이 역기능적인 분노표현에 대한 이해와 치료적 개입에 도움이 될 것이라 고 보고 매개변인을 통한 모형검증을 시도하였다.

Bernstein 과 Fink,(1998)는 아동기 외상을 신체적 학대와 방임, 정서적 학대와 방임, 성적 학 대 5 가지로 구분하였는데 이 중에서 정서적 학대와 방임을 합쳐서 정서적 외상이라고 본 연구에 서는 정의하였다. 정서적 학대는 아동에게 협박이나 언어적 폭력, 공격을 하거나 모욕감이나 수 치심을 갖게하는 행위나 적대적이고 거부적인 양육행동을 포함한다(권해수, 2003). 또한 정서적 방임은 보호자를 포함한 성인이 사랑과 소속감, 양육과 지지 등 아동이 기본적으로 필요한 정서 적, 심리적 필요를 제공하지 못하는 것을 의미한다(이유경, 2006). 발달과정동안 양육자의 무시, 굴욕, 갈등, 거부 또는 유관 의사소통의 결여 경험이 작은 외상으로 기능하며, 이후의 정서문제 로 작용할 수 있고(이지영 외, 2010에서 재인용) 초기 관계적 외상의 결과로 조절에 어려움을 겪는 정서를 분노의 행동적 측면인 공격성이라고 하였다(Schore, 2003). 학대경험이 있는 아동이 그렇지 않은 아동보다 분노의 표출정도가 높고 분노의 조절 정도는 더 낮게 나타나며, 아동이 지각한 학대 및 방임경험과 분노통제는 부적상관이 있고 분노표출과 분노 억제는 정적상관이 있었다(권효정, 2006; 오진환, 2003).

그렇다면 이러한 아동기 정서적 외상은 어떤 심리적 과정을 통해 역기능적 분노표현 즉 분노 표출과 분노 억제를 야기 하는 것일까. Wright 등(2009)의 연구에 의하면 정서적 학대와 방임과 이후 심리적 부적응의 관계는 개인이 내면화한 자신과 타인에 대한 도식이 주요 매커니즘으로 작용한다. 즉, 아동기 정서적 학대가 다른 종류의 학대보다 부정적인 자기인식에 더 강하게 관련 
되어 있으며(Alloy, Abramson, Smith, Gibb, \& Neeren, 2006; Gibb, 2002; Gibb, Abramson, \& Alloy, 2004), 부정적 자기인식은 아동기 정서적 학대와 이후 성인기의 무기력함과 우울증과의 관계를 완전 매개한다(Gibb, Alloy, Abramson, Rose, Whitehouse, \& Donovan, 2001)고 한다. 또한 자기 심리학적 접근에서 볼 때, 초기 외상의 결과로 인한 만성적인 분노를 가진 사람들은 취약한 자기를 가진 사람들이며 내면화된 부정적 인지도식인 낮은 자기존중감에 대한 하나의 방어로써 분노를 표현한다고 한다(Ornstein, 1999).

이러한 맥락에서 본 연구에서는 아동기 정서적 외상과 역기능적 분노표현의 매개변인으로 초 기부적응도식 가운데 단절 및 거절 도식을 상정하였다. 초기부적응도식은 Young(1990)이 여러 이론에서의 도식 개념을 바탕으로 개념화 한 것으로, 생애 초기 주요 타인과의 관계에서 형성되 어 일생 동안 정교화 되며, 한 개인의 생각, 느낌, 행동 및 대인관계에 중요한 영향을 미치게 된 다(Young, 1990). 처음에 16 개로 제안되었던 초기 부적응 도식은 이후 18 개로 확대되었고, 다시 5개 도식영역(1) 단절 및 거절, (2) 손상된 자율성 및 수행, (3) 손상된 한계, (4) 타인 중심성, (5) 과잉경계 및 억제)으로 분류되었다(Young, Klosko. \& Weishaar, 2005). 한편, Young(2005)은 5 개의 영역 중에서 단절 및 거절 영역에 속하는 심리도식을 가진 내담자들이 대개 가장 심각한 내담자들이라고 하였는데 이들 내담자들의 가족의 전형적인 모습은 불안정하고(유기/불안정), 학대적이며(불신/학대), 차갑고(정서적결핍), 거부적이며(결함/수치심), 외부 세상으로부터 고립 되어있다(사회적 고립/소외). 그들 대부분은 외상적인 아동기를 보냈으며, 어른이 된 뒤에는 여 러 가지 자기-파괴적인 관계를 무모하게 반복하거나 혹은 친밀한 관계를 아예 회피 해버린다 (Young, et. al., 2005).

이러한 단절 및 거절 도식은 개인의 정신건강과 관련이 있는 것으로 나타났다. 아동기 정서적 학대 경험이 우울에 영향을 미치는 데 있어 단절 및 거절도식 영역의 하위척도인 결함/수치심 도식이 매개하는 것으로 나타났으며(Wright, Crawford, \& Castillo, 2009), 단절 및 거절과 관련 된 도식이 우울, 불안과 같은 심리적 부적응 상태를 가장 많이 설명하는 것으로 나타났다 (Calvete, Estevez, Lopez, Ruiz, 2005; Welbaum, Coristine, Dagg, Pontefract, \& Jordan, 2002). 또한 단절 및 거절 관련 도식만을 변인으로 채택한 국내연구에서도 단절 및 거절 도식이 우울이 나 불안과 같은 부정적 정서와 관련이 있는 것으로 보고되면서(안하얀, 서영석, 2010, 2011), 단 절 및 거절 도식은 정서적 문제와 연관되는 도식으로 연구의 필요성이 꾸준히 제기 되어왔다. 요컨대, 아동기의 정서적 학대와 방임의 경험, 즉 지속적인 비판과 모욕, 비승인, 거절과 무시는 내면화되어 부정적 인지스타일로서 단절 및 거절 도식이 생겨나고 이는 다시 정서적 문제의 발 달에 영향을 미친다고 볼 수 있다.

한편, 우울과 불안과 같은 심리적 부적응은 부모로부터 학대경험이 있는 아동 및 성인에게서 자주 보고되는 대표적인 심리적 부적응 양상으로(신혜영, 최혜림, 2003; 황은수, 2006) 아동기에 
정서적 외상경험이 많을수록 우울수준이 높아진다(안동현, 2003). 분노표현과 여러 심리적 부적 응에 관련된 연구들이 다양하게 이루어져 왔는데 그 중에서는 우울과 불안은 분노와 가장 높은 연관성을 보이는 증상들로 여겨져 관련된 연구들이 수행되었다. 우울장애 환자들은 분노를 억제 하는 경향과 높은 연관성을 갖는다는 연구결과들(고영인, 1994; 최성일, 김중술, 신민섭, 조맹제, 2001)과 불안과 역기능적인 분노표현의 관계를 지지하는 연구가 있다(Hawkins \& Cougle, 2011).

이에 따라 본 연구에서는 아동기 정서적 외상이 단절 및 거절 도식, 심리적 부적응인 우울과 불안, 역기능적 분노표현이 가지는 관련성을 살펴보고 단절 및 거절 도식과 심리적 부적응 변인 에 의해서 어떤 방식으로 매개되는지 모형을 검증하였다. 연구모형은 단절 및 거절 도식과 심리 적 부적응 변인이 서로 관련성이 있을 것이라는 점에 착안해서 아동기 정서적 외상이 초기부적 응 도식인 단절 및 거절 도식에 영향을 미치고, 단절 및 거절 도식이 심리적 부적응을 일으키게 하는 방향으로 영향을 주어 역기능적인 분노표현을 나타나게 될 것으로 보았다.

한편, 본 연구에서는 경쟁모형을 두 가지로 가정하였다. 첫째, 경쟁모형 1 은 낮은 자존감과 같 은 부정적인 자기인식은 하나의 방어로서 분노를 유발하며(Ornstein, 1999), 아동기 외상이 불안 과 우울과 같은 심리적 부적응에 중요한 영향을 미친다는 선행연구(신혜영, 최혜림, 2003; 안동현, 2003)에 근거한 것으로, 아동기 정서적 외상과 역기능적 분노표현을 매개하는 변인으로 단절 및 거절 도식과 심리적 부적응 변인을 각각 상정하고, 두 변인이 각각 아동기 정서적 외상과 역기능 적 분노표현 사이의 관계를 매개할 것으로 보았다. 둘째, 경쟁모형 2는 아동의 학대경험이 높을 수록 아동의 분노표현이 높아진다는 선행연구(권효정, 2006; 오진환, 2003)에 근거하여 경쟁모형 1 에 아동기 정서적 외상에서 역기능적 분노표현으로 가는 직접 경로를 추가한 모형이다.

\section{․ 연구 방법}

\section{1. 연구대상}

본 연구는 서울과 경기, 인천에 소재한 4 년제 대학교에 재학 중인 대학생들을 대상으로 실시 하였다. 설문에 참여한 대학생들은 372 명이었으며 불성실하게 응답한 31 명의 자료를 제외한 341 명의 설문지를 자료 분석에 사용하였다. 341명 중 남학생이 180 명(52.79\%), 여학생이 161 명 (47.21\%)으로 남학생의 참여비율이 조금 높았다. 참여자들의 평균 연령은 21.82 세 $(S D=2.17)$ 였고 학년별로는 1학년 51명(14.96\%), 2학년 90명(26.39\%), 3학년 89명(26.10\%), 4학년 107명(31.38\%), 미기재 4 명 $(1.17 \%)$ 순으로 4 학년이 가장 높은 비중을 차지하였다. 


\section{2. 측정도구}

1) 아동기 정서적 외상

아동기 정서적 외상의 정도를 측정하기 위해서 Bernstein과 Fink(1998)가 개발하고, 이유경 (2006)이 번안한 아동기 외상 질문지(Childhood Trauma Questionnarie, CTQ)를 김은정(2010)이 타당화 한 것을 사용하였다. $\mathrm{CTQ}$ 는 총 25 문항으로, 정서적 학대와 신체적 학대, 정서적 방임, 신체적 방임, 성적 학대의 다섯 가지 하위척도에 대해 각각 5 문항씩 구성되어 있는데 이 중 정서 적 방임 5 문항은 역문항으로 구성되어 있다. 본 연구에서는 정서적 학대와 정서적 방임을 측정 하는 10 문항만을 사용하였다. 각 질문에 대한 응답은 '전혀 없음(1점)'에서 '자주 있음(4점)'의 4 점 Likert 식 척도이며, 점수가 높을수록 아동기 정서적 학대 및 방임의 경험 정도가 심함을 의미 한다. Bernstein 등(1998)의 연구에서는 하위요인 별 내적합치도(Cronbach's $\alpha$ )가 .81 .95로 보고되었다. 본 연구에서 정서적 학대 .77, 정서적 방임 .89로 나타났다.

\section{2) 초기부적응도식}

단절 및 거절 영역의 초기부적응 도식을 측정하기 위해 Young(1990)이 고안하고, Barnoff, Oei, 권석만과 조성호(2006)가 요인구조와 신뢰도를 검증한 단축판 초기부적응 도식 질문지 (Young Schema Questionnaires-Short Form: YSQ-SF)를 사용하였다. 이 척도는 기존의 초기부 적응 도식 질문지에서 요인분석을 통해 밝혀진 15 개의 도식에서 요인부하량이 큰 5 문항씩 뽑아 구성되어 있다. 본 연구에서는 초기부적응 도식의 다섯 가지 하위 척도 중 아동기 정서적 외상 경험과 심리적 부적응과 가장 관련이 큰 단절 및 거절 영역에 해당하는 도식만을 사용하였다. 단절 및 거절 영역에는 정서적 결핍, 유기/불안정, 불신/학대, 사회적 고립/소외, 결함/수치심 도식이 있으며 각 5 문항씩 총 25 문항이다. 각 문항에 대한 응답은 '전혀 동의 안함(1점)'에서 '전 적으로 동의함 (6점)'까지 6점 Likert 척도로 이루어져 있으며, 점수의 범위는 25에서 150점이다. 점수가 높을수록 초기부적응 도식을 많이 가지고 있음을 의미한다. 한국 대학생을 대상으로 한 Barnoff 등(2006)의 연구에서는 단절 및 거절 영역의 하위요인 별 내적합치도(Cronbach's $\alpha$ )가 정서적 결핍 .83 , 유기/불안정 .78 , 불신/학대 .82, 사회적 고립/소외 .90 , 결함/수치심 .84 였다. 본 연구에서는 정서적 결핍 .83 , 유기/불안정 .87 , 불신/학대 .82 , 사회적 고립/소외 .87 , 결함/수 치심 89 였다. 
3) 심리적 부적응

본 연구에서는 일상생활에서 경험하는 우울과 불안을 심리적 부적응의 주요 지표로 선택하여 사용하였다. 우울과 불안을 측정하기 위해 Derogatis(1977)가 개발하고 김광일, 김재환, 원호택 (1884)이 한국문화에 맞게 수정하여 표준화한 간이정신진단검사(Symptom-90-Revision; SCL-90-R)를 사용하였다. 이 척도는 신체화, 강박증, 대인예민성, 우울, 불안, 적대감, 공포불안, 편집증, 정신증 등 총 9 개의 증상을 측정하는 하위차원으로 구성되어 있는데 우울은 삶에 대한 희망 상실, 동기 결여, 활력 상실, 절망감 및 자살에 대한 생각 등으로 나타나는 기분이나 감정의 저조 등을 측정하며 총 13 개 문항으로 구성되어 있다. 불안은 신경과민, 긴장, 초조, 두려움 등과 관련되어 나타나는 신체적 증상을 측정하고 있으며 모두 10 개의 문항으로 구성되어 있다. 각 문 항은 일주일 동안 경험한 증상의 정도에 따라 '전혀 없다(0점)에서 '아주 심하다(4점)'의 5점 Likert 식 척도이고 합산점수가 낮을수록 정신건강 상태가 양호한 것을 의미한다. Derogatis(1977)의 연구에서 내적합치도(Cronbach's $\alpha$ )가 우울 .90, 불안 .85로 나타났으며 본 연구에서는 우울 .93, 불안 .91로 나타났다.

\section{4) 역기능적 분노표현}

분노표현양식을 측정하기 위해 상태-특성 분노표현 척도(State-Trait Anger Expression Inventory-Korean Version: STAXI-K)를 사용하였다. 이는 Spielberger(1988)가 개발한 상태-특성 분노표현 척도(State-Trait Anger Expression Inventory)를 전겸구, 한덕웅, 이장호와 Spielnberger(1997)가 번안, 타당화한 척도이다. 본래 STAXI-K는 분노 표현의 세 가지 양상인 분 노 억제, 분노표출, 분노 통제의 세 가지 하위요인을 비롯하여, 상태분노, 특성분노를 측정하는 두 가지 하위요인이 더해진 형태의 질문지로 총 다섯 가지 하위요인으로 이루어져 있다. 본 연구 에서는 기능적 척도인 분노 조절을 제외하고, 역기능적 척도인 분노표출 8 문항과 분노억제 8 문 항을 사용하였다. 각 질문에 대한 응답은 '전혀 아니다(1점)'에서 '매우 그렇다(4점)'의 4점 Likert 식 척도이며, 점수가 높을수록 분노표출과 억압 정도가 심함을 의미한다. 전겸구, 한덕웅, 이장 호와 Spielberger(1997)의 연구에서 분노억제요인과 분노표출요인의 내적합치도(Cronbach's $\alpha$ ) 가 각각 $.78, .79$ 로 나타났다. 본 연구에서는 분노억제요인 .64, 분노표출요인 .71 이었다.

\section{3. 분석방법}

자료의 특성을 알아보기 위해 각 변인별로 평균과 표준편차를 구하고, 각 변인 간의 관계를 
검토하기 위해 Pearson 상관계수를 산출하였다. 그리고 아동기 정서적 외상, 단절 및 거절도식, 심리적 부적응이 역기능적 분노표현에 미치는 영향력에 관한 모형을 검증하기 위하여 구조방정 식 모형검증을 실시하였다. 추정방법은 최대우도법을 사용하였으며 측정변인은 각 척도의 하위 요인으로 구성하였다. 모형 적합도는 표본크기에 덜 민감한 Comparative Fit Index(CFI), Tucker-Lewis Index(TLI), Root Mean Square Error of Approximation(RMSEA) 등을 이용하였 다. RMSEA는 절대적 적합도 지수로 .05이하(Browne \&Cudeck, 1993) 또는 .06이하(Hu \& Bentler, 1999)일 때 좋은 적합도, 08이하이면 보통 적합도 .10이상이면 나쁜 적합도로 판정된다. 이에 비하여 CFI와 TLI는 상대적 적합도 지수로 .90 이상이면 모형의 적합도가 좋은 것으로 해석 하였다(홍세희, 2000). 마지막으로 매개변인으로 선정된 단절 및 거절도식과 심리적 부적응의 매 개효과의 유의도를 확인하기 위해 Shrout와 Bolger(2002)의 제안에 따라 부트스트랩 절차를 활용 하였다. 부트스트랩 절차는 모수 분포를 알지 못할 때 모수의 경험적 분포를 생성시키는 방법으 로 본 연구에서는 1,000 개의 표본을 원자료 $(\mathrm{n}=341)$ 로부터 생성하여 신뢰구간 $95 \%$ 에서 간접효과 의 유의도를 검증하였다. 모든 통계분석은 SPSS win 17.0 과 Amos 18.0 프로그램을 이용하였다.

\section{III. 연구 결과}

\section{1. 기술통계와 상관분석}

아동기 정서적 외상, 단절 및 거절도식, 심리적 부적응, 역기능적 분노표현의 평균, 표준편차 와 각 변인간의 상관계수를 표 1 에 제시하였다. 표 1 에서 보면 아동기 정서적 외상수준이 높을수 록 단절 및 거절도식을 더 많이 가지고 있고 심리적 부적응과 역기능적인 분노표현을 더 많이 경험하는 경향이 있음을 알 수 있다. 단절 및 거절도식과 심리적 부적응, 역기능적 분노표현 사 이에는 정적 상관을 보여, 단절 및 거절도식을 많이 가지고 있을수록 심리적 부적응과 역기능적 분노표현 경향이 강하고, 심리적 부적응이 심할수록 역기능적 분노표현 경향이 더 커질 수 있는 것으로 추론된다.

\section{2. 측정모형 검증}

연구모형을 검증하기에 앞서 측정 변인들이 해당 잠재변인을 적절하게 구인하는지 확인하기 위해 확인적 요인분석(CFA)을 실시하였다. 그 결과 측정모형은 자료에 적합한 것으로 나타났 다. $\chi^{2}(1205, N=341)=2152, \mathrm{p}<.001 ; \mathrm{CFI}=.91 ; \mathrm{TLI}=.91 ; \mathrm{RMSEA}=.048$. 또한 측정변인들 
에 대한 해당 잠재변인의 요인부하량을 살펴보면, 아동기 정서적 외상은 $.67 \sim ~ .88$, 단절 및 거절 도식은 $.62 \sim .92$, 심리적 부적응은 $.60 \sim .84$, 역기능적 분노는 .59 .80 로 모두 $p<.001$ 수준에 서 유의하였다. 따라서 11 개의 측정변인으로 4 개의 잠재변인을 구인하는 것이 타당한 것으로 확 인되었다.

\section{3. 구조모형 검증}

아동기 정서적 외상과 단절 및 거절도식, 심리적 부적응이 역기능적 분노표현에 미치는 영향 력을 알아보기 위하여 연구모형과 경쟁모형을 설정하고 각 적합도를 비교하였다. 연구모형은 아 동기 정서적 외상이 단절 및 거절도식에 영향을 주고 단절 및 거절도식이 심리적 부적응에 영향 을 주어 다시 심리적 부적응이 역기능적 분노표현에 차례로 영향을 미치는 매개모형으로 하였 다. 이것에 대한 경쟁모형 1 은 아동기 정서적 외상이 단절 및 거절도식과 심리적 부적응 각각을 통해서 역기능적 분노표현에 간접적인 영향력만을 가지는 모형이며 경쟁모형 2는 경쟁모형 1에 아동기 정서적 외상에서 역기능적 분노표현으로 가는 직접 경로를 추가한 모형이다. 그림 1 은 연구모형을, 그림 2는 경쟁모형 1을, 그림 3은 경쟁모형 2를 도식화한 것이다. 설정된 세 가지 구조모형 간 적합도 비교를 통해 자료를 보다 잘 설명하는 모형을 선택하고자 하였다.

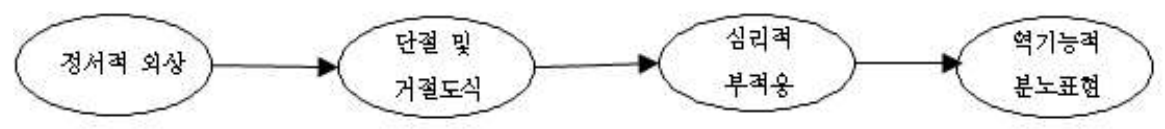

[그림 1] 연구모형

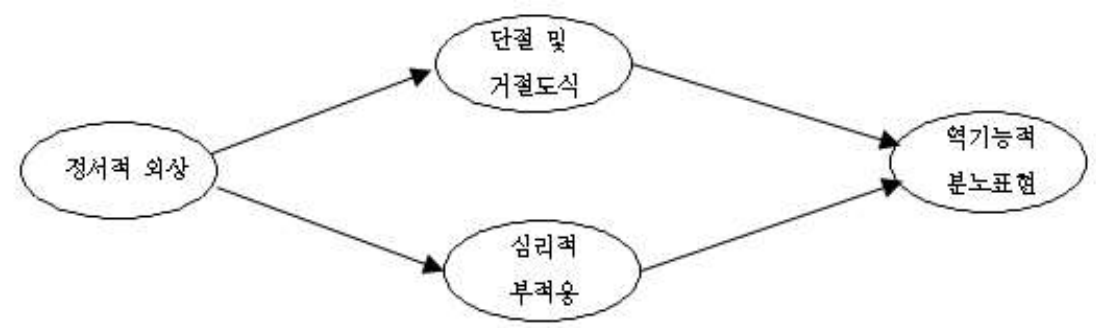

[그림 2] 경쟁모형 1 


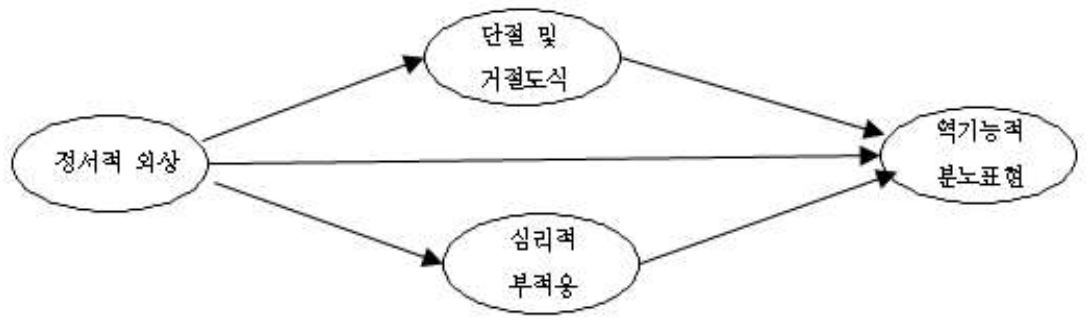

[그림 3] 경쟁모형 2

<표 1> 정서적 외상, 단절 및 거절도식, 심리적 부적응, 역기능적 분노표현의 상관, 평균, 표준편차

\begin{tabular}{|c|c|c|c|c|c|c|c|c|c|c|c|c|c|c|c|}
\hline & 1 & 2 & 3 & 4 & 5 & 6 & 7 & 8 & 9 & 10 & 11 & 12 & 13 & 14 & 15 \\
\hline 1 & 1 & & & & & & & & & & & & & & \\
\hline 2 & $.552 * *$ & 1 & & & & & & & & & & & & & \\
\hline 3 & $.871 * *$ & $.890 * *$ & 1 & - & & & & & & & & & & & \\
\hline 4 & $.463 * *$ & $.498 * *$ & $.545 * *$ & 1 & & & & & & & & & & & \\
\hline 5 & $.479 * *$ & $.310 * *$ & $.445 * *$ & $.528 * *$ & 1 & & & & & & & & & & \\
\hline 6 & $.247 * *$ & $.290 * *$ & $.306 * *$ & $.422 * *$ & $.528 * *$ & 1 & & & & & & & & & \\
\hline 7 & $.381 * *$ & $.256 * *$ & $.359 * *$ & $.604 * *$ & $.446 * *$ & $.453 * *$ & 1 & & & & & & & & \\
\hline 8 & $.385 * *$ & $.284 * *$ & $.377 * *$ & $.508 * *$ & $.519 * *$ & $.560 * *$ & $.630 * *$ & 1 & & & & & & & \\
\hline 9 & $.499 * *$ & $.419 * *$ & $.520 * *$ & $.778^{* * *}$ & $.808 * *$ & $.777 * *$ & $.775 * *$ & $.766 * *$ & 1 & & & & & & \\
\hline 10 & $.304 * *$ & $.167 * *$ & $.264 * *$ & $.270 * *$ & $.382 * *$ & $.412 * *$ & $.309 * *$ & $.395 * *$ & $.452 * *$ & 1 & & & & & \\
\hline 11 & $.356 * *$ & $.270 * *$ & $.353 * *$ & $.401 * *$ & $.413 * *$ & $.417 * *$ & $.406 * *$ & $.404 * *$ & $.522 * *$ & $.710 * *$ & 1 & & & & \\
\hline 12 & $.360 * *$ & $.243^{* * *}$ & $.340 * *$ & $.372 * *$ & $.431 * *$ & $.448 * *$ & $.393 * *$ & $.432 * *$ & $.531 * *$ & $.902 * *$ & $.944 * *$ & 1 & & & \\
\hline 13 & .097 & .003 & .055 & -.009 & .104 & $.171 * *$ & .039 & .001 & .094 & $.116 *$ & $.115 *$ & $.125 *$ & 1 & & \\
\hline 14 & $.198^{* * *}$ & .075 & $.152 * *$ & $.162 * *$ & $.300 * *$ & $.276 * *$ & $.188 * *$ & $.194 * *$ & $.298 * *$ & $.351 * *$ & $.315 * *$ & $.357 * *$ & $.319 * *$ & 1 & \\
\hline 15 & $.187 * *$ & .052 & $.133 *$ & .104 & $.260 * *$ & $.281 * *$ & $.149 * *$ & $.131 *$ & $.253 * *$ & $.301 * *$ & $.276 * *$ & $.310 * *$ & $.768 * *$ & $.852 * *$ & 1 \\
\hline $\mathrm{M}$ & 1.45 & 1.50 & 1.47 & 1.64 & 2.16 & 2.06 & 1.70 & .37 & 1.59 & .64 & 1.04 & .84 & 1.97 & 2.10 & 2.04 \\
\hline $\mathrm{SD}$ & .61 & .66 & .56 & .78 & 1.00 & .93 & .76 & .42 & .61 & .70 & .92 & .75 & .63 & .77 & .57 \\
\hline
\end{tabular}

$* p<.05, * * p<.01, * * * p<.001$

1. 정서적 학대 2. 정서적 방임 3. 정서적 외상 전체 4. 정서적 결핍 5. 유기불안정 6. 불신학대 7. 사회적 고립 8. 수치심 9. 단절 및 거절도식 전체 10. 불안 11 우울 12 . 심리적 부적응 전체 13. 분노표출 14. 분노억제 15. 역기능적 분노표현 전체

<표 2> 연구모형과 경쟁모형에 대한 적합도 지수

\begin{tabular}{cccccccc}
\hline & $\chi 2$ & $d f$ & $T L I$ & $C F I$ & $N F I$ & $A I C$ & $R M S E A$ \\
\hline 연구모형 & 124.21 & 36 & .904 & .937 & .915 & 206.212 & .085 \\
\hline 경쟁모형 1 & 156.57 & 35 & .864 & .914 & .893 & 218.572 & .101 \\
\hline 경쟁모형 2 & 155.59 & 34 & .860 & .913 & .893 & 219.594 & .103 \\
\hline
\end{tabular}




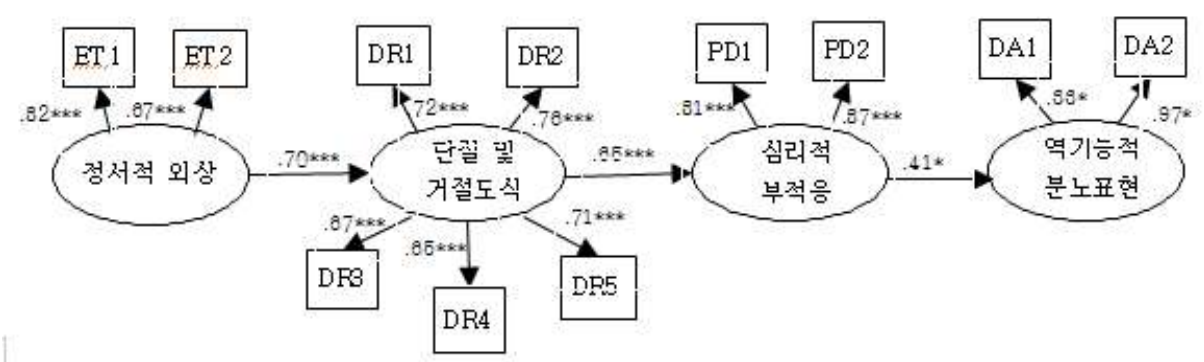

[그림 4] 최종모형

$* p<.05$, *** $p<.001$

ET1 정서적 학대, ET2 정서적 방임,

$\mathrm{DR} 1$ 정서적 결핍, DR2 유기불안정, DR3 불신학대, DR4 사회적 고립, DR5 수치심,

$\mathrm{PD} 1$ 불안, $\mathrm{PD} 2$ 우울,

$\mathrm{DA} 1$ 분노표출, DA2 분노억제

<표 3> 연구변인 간 직간접효과 검증 결과

\begin{tabular}{|c|c|c|c|c|c|c|}
\hline & 경로 & & 직접효과 & 간접효과 & 총 효과 & $\begin{array}{c}\text { Sobel } \\
\text { Test }(z)\end{array}$ \\
\hline 정서적 외상 & $\rightarrow$ 단절 및 거절도식 & & $.70^{* * *}$ & - & $.70^{* * *}$ & - \\
\hline 단절 및 거절도식 & $\rightarrow$ 심리적 부적응 & & $.65^{* * * *}$ & - & $.65^{* * *}$ & - \\
\hline 심리적 부적응 & $\rightarrow$ 역기능적 분노표현 & & $.41^{*}$ & - & $.41^{*}$ & - \\
\hline 정서적 외상 & $\rightarrow$ 단절 및 거절도식 & $\rightarrow$ 심리적 부적응 & - & $.46^{* *}$ & $.46^{* *}$ & 5.98 \\
\hline 단절 및 거절도식 & $\rightarrow$ 심리적 부적응 & $\rightarrow$ 역기능적 분노표현 & - & $.27^{* *}$ & $.27^{* *}$ & 2.26 \\
\hline
\end{tabular}

$N=341 . * p<.05, * * p<.01, * * * p<.001$. 표에 제시된 계수들은 표준화된 수치임.

본 연구에서 설정한 3 개 모형의 적합도를 비교한 결과는 표 2와 같다. 연구모형과 경쟁모형 1,2 의 적합도를 비교한 결과 경쟁모형 1 과 2의 적합도는 RMSEA가 1.0 을 넘는 등 전반적으로 양호하지 않았다. 반면 연구모형의 적합도는 전체적인 기준치(TLI, CFI, NFI>.90)에 가까워 이를 선택하는 것이 타당하다고 할 수 있겠다. 비록 RMSEA가 기준 값에 도달하지 못했지만 모형 오류가 작은 경우에도 자유도가 작으면 RMSEA의 값이 클 수 있기 때문에 CFI와 NFI를 적합도 의 판단기준으로 적용하였다(홍세희, 2000).

아동기 정서적 외상과 단절 및 거절도식, 심리적 부적응, 역기능적 분노표현 간 구조모형의 모수추정치를 도식화한 것은 그림 4 와 같다. 그림 4 를 보면 아동기 정서적 외상이 단절 및 거절 도식에 정적으로 영향을 주고 단절 및 거절 도식이 심리적 부적응에 주는 영향도 정적으로 유의 미하였다. 그리고 심리적 부적응이 역기능적인 분노표현에 영향을 주는 것 역시 정적으로 유의 미했다. 한편, 초기부적응도식과 심리적 부적응의 매개효과 검증을 위하여 본 연구에서는 1000 개의 표본을 생성하는 부트스트랩 절차를 실시하였으며 이후 sobel test에 의한 유의도 확인결과 
를 표3에 제시하였다. 우선 아동기 정서적 외상이 단절 및 거절도식을 거쳐 심리적 부적응으로 가는 간접경로가 유의하고 단절 및 거절 도식이 심리적 부적응을 거쳐 역기능적인 분노표현으 로 가는 간접경로가 유의한 것으로 나타났다. 따라서 단절 및 거절도식과 심리적불편감이 순차 적으로 정서적 외상을 매개하여 역기능적인 분노표현에 영향을 미친다고 할 수 있겠다.

\section{VI. 논의 및 결론}

본 연구는 역기능적 분노표현에 대한 이해를 더하고자 아동기 정서적 외상과 역기능적 분노 표현간의 관계에서 단절 및 거절도식과 심리적 부적응을 매개변인으로 가정하여 모형을 검증하 였다. 연구결과를 선행연구와 비교하고, 본 연구결과가 상담실제 및 후속연구에 지니는 시사점 을 논하면 다음과 같다.

먼저 각 척도들 사이의 관계를 보면 독립변인인 아동기 정서적 외상과 종속변인인 역기능적 분노표현은 정적상관이 있는 것으로 나타났다. 이는 정서적 외상은 특성분노수준 및 역기능적 분노표현 방식을 유의미하게 예측한다(이지영, 손정락, 2010; 조한익, 최종환, 2013)는 선행연구 와 일치한다. 한편, 본 연구에서는 정서적 외상이 역기능적인 분노표현의 하위척도 중에서 분노 표출과의 유의성은 확인할 수 없었으나 분노억제와는 유의한 정적상관이 있는 것으로 나타났다. 이는 아동기에 경험한 정서적 학대는 분노를 표출하기보다는 억제하는 것과 관련된다(권효정, 2006)는 선행연구 결과와 일치한다. 따라서 아동기에 정서적인 학대를 경험한 사람들은 부적절 하게 분노를 억제하기가 쉬운데 상대를 속으로 비난하거나 관계를 피해버리는 방식을 취함으로 써 또 다른 정서적 부적응이나 대인관계적 문제를 유발할 가능성이 있다

매개변인인 단절 및 거절도식과 심리적 부적응, 그리고 종속변인인 역기능적인 분노표현도 정적상관을 나타났다. 즉 단절 및 거절도식을 많이 가지고, 우울과 불안 수준이 높으면 역기능적 인 분노표현수준이 높은 것으로 보인다. 이는 우울수준은 분노억제 및 표출과 유의한 정적상관 을 보이며(이훈진, 2000) 불안하고 우울할수록 분노표출과 분노억제를 많이 한다(한동화, 2009) 는 선행연구와도 일치한다. 또한 비합리적 신념은 역기능적인 분노를 일으키며(서수균, 2004), 결함도식과 결핍도식으로 구성된 초기부적응도식은 역기능적 분노와 강한 상관을 가진다는 선 행연구(이지영, 손정락, 2010)와도 부분적으로 일치한다. 한편, 단절 및 거절도식의 경우 역기능 적인 분노표현 가운데 분노억제와 유의한 정적인 상관이 확인되었으며 분노표출과는 부분적으 로 유의한 정적상관이 확인되었다. 이는 단절 및 거절도식이 역기능적 분노표현 중 특히 분노억 제를 예언하는데 보다 중요한 변인인 것으로 생각될 수 있다.

또한 독립변인인 아동기 정서적 외상과 단절 및 거절도식, 심리적 부적응 등 매개변인들과의 
관계 역시 유의한 정적상관관계를 보였다. 이는 아동기 정서적 학대 경험이 우울에 영향을 미치 는데 있어 단절 및 거절 도식 영역의 하위척도인 결함/수치심 도식이 매개하고(Wright, et. al., 2009), 단절 및 거절 도식이 우울, 불안 등 부정적 정서를 가장 많이 설명하는(안하얀, 서영석, 2010, 2011; Calvete, et. al., 2005; Welbaum et. al., 2002)것으로 나타난 선행연구들과 일치한다. 즉 아동기에 정서적 학대나 방임을 경험한 경우 단절 및 거절도식을 많이 가지게 되고 이에 따라 심리적인 불안과 우울을 더 많이 경험할 가능성이 있다. 본 연구에서는 특히 정서적 외상의 하위 요인 중 정서적 방임은 단절 및 거절도식의 하위요인 중 정서적 결핍과 높은 정적상관을 보였고 정서적 외상의 정서적 학대는 단절 및 거절도식의 유기불안정과 높은 정적상관을 보였다.

아동기 정서적 외상과 단절 및 거절도식, 심리적 부적응이 역기능적인 분노표현에 미치는 경 로와 영향력을 알아보기 위하여 이를 구조방정식으로 검증하였다. 검증결과, 아동기 정서적 외 상이 단절 및 거절도식에 영향을 주고 단절 및 거절도식이 심리적 부적응에 영향을 주며, 다시 심리적 부적응이 역기능적인 분노표현에 영향을 미치는 모형의 적합도가 가장 좋게 나왔다. 즉 아동기 정서적 외상수준이 높으면 단절 및 거절도식과 같은 초기부적응도식을 더 많이 가지게 되고 이는 우울과 불안과 같은 심리적 부적응을 강화하면서 역기능적인 분노표현에 영향을 미 치는 것으로 보인다. 이러한 연구결과는 자동적인 부정적 자기연합이 지속적인 정서적 외상과 우울과 불안을 부분적으로 매개한다는 연구결과(Harmelen, Jong, Glashouwer, Spinhoven, Penninx \& Elzinga, 2010)에 부합되며 어릴 적 경험한 지속적인 비판과 모욕, 혹은 비승인, 거절, 무시 등이 자신에 대한 전반적인 부정적 신념으로 내면화 되게 되면, 이때 촉발된 결핍감과 수치 심이 이후 불안과 우울감으로 장기적인 부정적 영향을 미치게 된다는 Wright 등(2009)의 연구 결과와도 부분적으로 일치한다. 김은정(2010) 역시 아동기 외상이 성인기 우울에 대한 직접적인 설명변인으로 작용하기보다는 초기부적응도식이 매개역할을 함을 밝혀 본 연구와 일치하는 결 과를 보였다.

정서적으로 학대적이고 방임하는 방식을 취하는 부모들은 아이에게 자기 스스로에 대해서 실 망스럽고 사랑이나 주목을 받을 가치가 없다는 메시지를 전달하게 되고 핵심적인 정서욕구를 충족시키지 못한 결과로 아동은 자기패배적인 감정과 사고의 패턴을 발달시키게 되는데 이는 자신과 세상에 대해서 알고 있는 것 자체가 되게 된다(유성진, 권석만, 2008). 이렇게 형성된 초 기부적응도식은 내담자의 인지, 정서, 행동 및 대인관계에 중요한 영향을 미치고, 이후 경험을 처리하는 과정에 지속적으로 관여하게 된다(유성진 등, 2008). 즉, 단절 및 거절도식과 같은 초기 부적응도식이 심각하면 할수록 다양한 상황에서 더 쉽게 활성화되며 정서적인 우울과 불안과 같은 부정적인 감정은 더 강렬하며 더 오랫동안 지속이 된다.

하지만 이러한 심리적인 불편감은 분노와 같은 이차적 반응에 의해 의식으로 자각되는 것이 방해될 수 있다. 즉 본 연구결과에 의하면 아동기 외상으로 인해 형성된 초기부적응도식은 개인 
으로 하여금 우울과 불안과 같은 심리적 부적응을 유발하지만 이차적 반응인 분노에 의해 심리 적 부적응이 의식으로 자각되는 것이 방해될 수 있다는 것이다. 이는 아동을 대상으로 한 연구에 서 우울 수준이 높을수록 분노억제와 분노표출이 많이 나타나고(이미영, 2006), 우울감이 높은 사람들은 무기력함으로 인해 분노감정에 대해 분노조절보다는 과격한 행동을 보이거나 겉으로 표현하지 않고 억누르는 경향이 높다(이명희, 2011; 정유진, 2013)는 선행연구결과에 의해 지지 될 수 있다. 자기심리학에서도 초기 양육자나 중요인물에 의한 심리적 외상에 의해 생겨난 분노 는 결국 내면의 심리적 취약성을 반영한 것이라고 했는데 죄책감이나 무가치감 혹은 우울감과 같은 고통스러운 감정을 느끼는 대신 다른 사람을 비난하거나 공격하게 되고 이는 분노를 유발 한 기저의 근원적인 감정을 차단하는 역할을 할 수 있다.

따라서 타인을 향한 주체하기 힘든 분노감으로 상담실을 찾는 내담자들의 경우 그들의 과격 한 공격행동이나 타인에 대한 비난, 혹은 관계에서의 철수 등 표면적으로 드러난 역기능적인 분 노표현방식에 주목하기 보다는 그러한 대처가 내담자에게 어떤 심리적인 기능을 하는지에 대한 보다 선행된 이해가 필요할 것으로 보인다. 정서적으로 학대받고 방임된 발달배경으로 인해 발 생된 정서적 결핍감이나 수치심등의 부정적인 인지 도식들은 심리적으로 취약하게 만들고 자신 들의 진정한 욕구를 느끼는 대신 부적절한 분노표현으로 감정을 차단 해왔을 가능성이 있다. 또 한 그들의 심리적 부적응을 다룸에 있어 내담자가 그들의 경험을 평가하고 그러한 사건들이 어 떤 의미를 부여하는지를 도와주는 것 또한 중요한 과정인데 Wright, Crawford, 과 Sebastian, (2007) 에 의하면 수치심은 매우 혐오스러운 정서적 경험이고 자신에 대한 깊은 부정적 평가와 연관되어 있기 때문에 수치심을 경험하는 개인들은 자주 숨겨나 사라지고 싶어하는 경향이 있 다. 이런 노력 과정에서 개인은 학대의 기억이나 생각을 자신의 마음에서 밀어내려고 하게 되고 결과적으로 자신의 과거 경험과 해리될 수 있는데 이러한 과정은 외상경험의 정서적, 인지적 과 정을 방해하고 이는 다시 외상경험에서의 회복을 방해한다. 따라서 상담 중에 내담자에게 떠오 를 수 있는 수치심과 같은 부적응적인 도식들을 민감하게 잡아서 자신의 경험을 재해석하게 함 으로써 새로이 재구성하도록 도와줄 필요가 있을 것이다.

또한 개인이 관계에서 잦은 분노를 경험하며 타인을 향해 과도한 비난을 하게 되거나 혹은 관 계에서 철수하는 패턴을 보인다면 그러한 분노경험에 앞서 그 관계에서 좌절된 자신의 욕구나 두려움에 대해서 먼저 인식할 필요가 있을 것이다. 즉, 자신이 진정으로 바랐거나 피하고 싶었던 것에 대해서 자각하고 이해하는 과정 속에서 우울과 불안과 같은 고통스러운 정서에 맞닿게 될 수 있을 것이다. 이러한 자신의 취약함에 대한 인식은 오래 동안 자신이 인식하지 못한 채 내면화 시켜온 부적응도식의 내용과 관련이 되므로 그 동안 자신의 경험에 스스로가 부여해 온 평가와 의미에 대해서 구체적으로 생각해볼 필요가 있다. 또한 그러한 부적응도식을 발달시킬 수밖에 없었던 초기 발달과정에 대한 스스로의 이해를 해 나가는 경험을 통해서 궁극적으로는 심리적인 
부적응과 분노 등을 스스로 통제해 나갈 수 있는 힘을 얻을 수 있을 것으로 여겨진다.

본 연구의 함의는 아동기 정서적 외상과 역기능적인 분노표현의 관계를 경험적으로 확인하였 다는 점에 있다. 즉 역기능적인 분노표현에 이르는 기제에 대한 또 하나의 인과적 관련성을 설정 하여 확인하였는데 특히 분노라는 정서를 다룸에 있어 그 기저에 있는 취약성과 무력감에 다가 가 이를 인식하는 것이 수반되어야만 분노를 통제하고 욕구를 충족시킬 수 있는 새로운 방법이 효과를 발휘할 수 있다는 것을 경험적으로 검증하였다.

본 연구의 한계는 다음과 같다. 먼저 연구대상이 서울과 경기 및 인천 지역의 대학교에 재학 중인 대학생들을 대상으로 자료를 수집했기 때문에, 연구결과를 성인에게도 일반화시키기 어려 운 한계가 있다. 따라서 모집단을 대표할 수 있는 표집을 통해 본 연구결과가 재현되는지를 확인 할 필요가 있다. 또한 본 연구에서 설문지가 모두 자기보고식으로 측정되었기 때문에 연구 대상 자가 실제의 아동기 정서적 외상에 대해 기억에만 의존해 낮게 보고했을 가능성이 있고 초기부 적응도식이나 분노표현방식에 대해 사회적으로 바람직한 방향으로 왜곡했을 가능성을 배제할 수 없을 것이다. 특히 역기능적 분노표현의 경우 신뢰도 계수가 다소 낮게 나왔는데(분노억제요 인 .64, 분노표출요인 .71) 그 이유로서 한 가지 추측 가능한 것은 문항에 답하는 응답자가 자신 의 객관적 상태에 대해서 정확히 자각하기 보다는 주관적으로 답변했을 가능성이다. 예를 들어 신뢰도 계수가 .64로 낮게 나온 분노억제의 문항을 살펴보면 '뚱해지거나 토라진다', '상대의 시 선을 피한다', '다른 사람들이 알고 있는 것보다 분통이 더 나있다' 등이 있는데 이러한 문항들에 답하는 응답자의 자기보고에 의존한 결과 응답자 자신의 당시 상태나 상황에 따라 왜곡되었을 가능성이 있을 것으로 보여진다. 따라서 추후 연구에서는 이러한 부분을 보완할 수 있도록 자기 보고 이외에 가까운 주변인들의 지각을 포함하는 보다 객관성을 확보할 수 있는 보완된 측정이 필요할 것으로 여겨진다. 마지막으로, 본 연구에서는 가장 파괴적이고 손상이 큰 것으로 보고된 단절 및 거절 도식만을 매개변인으로 채택하여 다른 변인들과의 관련성을 살펴보았는데 후속연 구에서는 보다 다양한 부적응적인 도식개념들을 사용하여 보다 세분화된 심리적 부적응과 분노 의 신념이나 태도와 같은 변인들과의 관련성을 탐색할 필요가 있을 것이다. 


\section{참고문헌}

고영인(1994). 대학생의 분노표현 양식과 우울 및 공격성과의 관계. 박사학위논문, 부산대학교. 권해수(2003). 성학대 피해 청소년의 적응유연성에 영향을 미치는 관련변인 연구. 박사학위논문, 홍익대학교.

권효정(2006). 아동이 지각한 학대경험과 자아조절력, 분노표현과의 관계. 석사학위논문, 숙명여 자대학교.

김광일, 김재환, 원호택(2006). 간이정신진단검사 실시요강. (pp.8 11) 중앙문화사.

김은정(2010). 아동기 외상과 초기성인기 우울수준과의 관계: 초기부적응도식과 정서표현양가성

및 회피대처방식의 매개효과. 박사학위논문, 경북대학교.

서수균(2004). 분노와 관련된 인지적 요인과 그 치료적 함의. 박사학위논문, 서울대학교.

신혜영, 최혜림(2003). 부모로부터의 학대경험과 공격성 및 대인불안간의 관계: 초등학교 고학년 아동을 중심으로. 한국심리학회지: 상담 및 심리치료, 15(2), 295-307.

아동보호전문기관 (2013). 2012년 전국아동학대현황보고서. http://korea1391.org 안동현(2000). 신고 된 아동에서 학대 후유증 연구. 보건복지부 시행 정책과제 연구개발사업 최 종보고서(HMP-99-P-0011). 서울: 보건복지부.

안하얀, 서영석(2010). Young의 단절 및 거절 도식, 부정적 기분, 대인관계문제, 정서적 과민반응

과 정서적 단절의 매개효과 검증. 한국심리학회지: 일반, 29(4), 847-865.

안하얀, 서영석(2011). 성인애착과 Young의 단절 및 거절 도식에 따른 집단 분류와 우울, 불안 및 대인관계문제에 대한 집단 간 차이. 한국심리학회지: 상담 및 심리치료, 23(4) ,943-969.

이명희(2011). 부모에 대한 애착 및 우울감이 분노표현방식에 미치는 영향: 중학생을 중심으로. 석사학위논문, 동아대학교.

이미영(2006). 아동의 우울수준에 따른 귀인성향 및 분노표현방식간의 관계. 석사학위논문, 명지 대학교.

이유경(2006). 여대생의 아동기 외상경험이 심리적 증상과 대인관계문제에 미치는 영향: 애착의 매개효과를 중심으로. 석사학위논문, 이화여자대학교.

이지영, 손정락(2010). 아동기 정서적 외상과 역기능적 분노간 관계에서 불안정애착과 초기부적 응 도식의 매개역할 검증. 한국심리학회지: 건강, 15(4),841-851.

이훈진(2000). 분노표현양식과 편집증 및 우울의 관계. 한국심리학회지: 임상, 19(3), 427-438. 오진환(2003). 아동의 피학대 경험이 분노표현방식에 미치는 영향에 관한 연구. 석사학위논문, 
숭실대학교.

유성진, 권석만(2008). 심리치료에서 도식과 양식 개념에 대한 고찰. 한국심리학회지: 일반, 27(1), 91-117.

전겸구(1999). 분노에 관한 기초 연구. 재활심리연구. 6(1), 173-190.

전겸구, 한덕웅, 이장호, Spielberger, C. D. (1997). 한국판 STAXI 척도 개발: 분노와 혈압. 한국 심리학회지: 건강, 2, 60-78.

전현숙, 손정락,(2011). 역기능적 분노표현 및 비합리적 신념과 마음챙김의 관계. 한국심리학회 지: 일반, 30(2), 377-396.

정유진(2013). 청소년의 우울증상과 신체화 증상의 관계에서 분노표현방식의 중재효과. 석사학 위논문, 숙명여자대학교.

조한익, 최종환(2013). 아동기 정서적 외상이 초기 성인기 역기능적 분노표현에 미치는 영향에서 부정적 용서신념의 매개효과. 청소년학연구. 20(9), 125-148.

최성일, 김중술, 신민섭, 조맹제(2001). 분노표현방식과 우울 및 신체화 증상과의 관계. 신경정신 의학. $40(3), 425-433$.

한동화(2009). 청소년의 분노표현방식에 대한 불안, 우울, 자존감의 영향. 석사학위논문, 서울여 자대학교 특수치료전문대학원.

홍세희(2000). 구조방정식 모형의 적합도 지수 선정기준과 그 근거. 한국심리학회지: 임상, 19(1), 161-177.

황은수(2006). 아동의 학대경험이 우울과 불안에 영향을 미치는 자기인식정서의 매개효과. 석사 학위논문, 숙명여자대학교.

Allen, J. (2001). Traumatic relationships and serious mental disorders. Chichester, England: Wiley \& Sons.

Allen, J. (2005). Coping With Trauma (Hope Through Understanding). Amer Psychiatric Pub Inc.

Alloy, L. B., Abramson, L. Y., Smith, J. M., Gibb, B. E., \& Neeren, A. M. (2006). Role of parenting and maltreatment histories in unipolar and bipolar mood disorders: mediating bu cognitive vulnerability to depression. Clinical Child and Family Psychology Review. 9, 23-64.

Baranoff, J., Oei, T. P., Kwon. S. M., \& Cho, S. H. (2006). Factorstructure and internal consistency ofthe Young Schema Questionnaire (Short Form) in Korean and Australian samples. Journal of Affective Disorders, 93, 133-140.

Bernstein, D. P., \& Fink, L.(1998). Childhood Trauma Questionnaire: Aretrospective self-reportmanual. San Antonio,TX: The Psychological Corporation

Bilodeau, I. (1992). The Anger Workbook New York: MIF Books. 
Bowlby, J. (1980). Attachment and loss: Loss. NY: Basic Books.

Calvete, E., Estévez, A., López, E., \&Ruiz, P. (2005). The Schema Questionnaire-Short Form: Structure and relationship with authomatic thoughts and symptoms of affective disorders. European Journal of Psychological Assessment, 21, 90-99.

Derogatis L R., \& Cleary P. A. (1977). Factorial invariance across gender for the primary symptom dimensions of the SCL-90-R. BrJSocCinPsychol, 35(16), 347-356.

Egeland, B. (2009). Childhood emotional maltreatment and developmental psychopathology. Child Abuse\& Neglect, 33(1), 22-26.

Gibb, B. E. (2002). Childhood maltreatment and negative cognitive styles. A quantitative and qualitative review. Clinical Psychology Review. 22, 223-246.

Gibb, B. E., Abramson, L. Y., \& Alloy, L. B. (2004). Emotional maltreatment from parents. verval peer victimization, and cognitive vulnerability to depression. Cognitive Therapy and Research, 28, 1-21.

Gibb, B. E., Alloy, L. B., Abramson, L. Y., Rose, D. T., Whitehouse, W. G., \& Donovan, P. (2001). History of child maltreatment, negative cognitive styles and episodes of depression in adulthood. Cognitive Therapy and Research, 25, 426-446..

Gottlieb, M. M. (1999). The angry self: A comprehensive approach to anger management. Phoenix, Arizona: Zeig, Tucker \& Co. Press.

Greenberg, L. S. (2001). Emotion-focused therapy. American Psychological Association. Washington DC.

Greenberg, L. S., \& Paivio, S. C. (2003). Working with Emotions in Psychotherapy. Guilford Publications.

Harmelen, AL., Jong, P. J., Glashouwer, K. A., Spinhoven, P., Penninx, B. W.J.H., \& Elzinga, B. M. (2010). Child abuse and negative explicit and automatic self-association: The cognitive scars of emotional maltreatment. Behaviour Research and Therapy, 48, 486-494.

Hawkin, K. A., \& Cougle, J. R. (2011). Anger problem across the anxiety disorders: findings from a population-based study. Depression and Anxiety, 28(2), 145-152.

Mullen, P. E., Martin, J. L., Anderson, J. C., Romans, S. E. \& Herbison, G. P.(1996). The long -term impact of the physical, emotional, and sexual abuse of children: A community study. Child Abuse \& Neglect. 20(1), 7-21.

Ornstein, P. H. (1999). Conceptualization and treatment of rage in self psychology. Journal of Clinical of Psychology. 55(3), 283-293. 
Schore, A. (2001). Dysregulation of the right brain: A fundamental mechanism of traumatic attachment and the psychopathogenesis of posttraumatic stress disorder. Australian and New Zealand Journal of Psychiatry, 36, 9-30.

Schore, A. (2003). "Early relational trauma, Disorganized attachment \& the development of a predisposition to violence.: In M. F. Solomon \& D. J. Siegel(Eds.). Healing Trauma: Attachment, mind, body, and brain. (pp 107-167), NY: Norton.

Shrout, P. E., \& Bolger, N. (2002). Mediation in experimental and nonexperimental studies: New procedures and recommendations. Psychological Methods, 73), 422-.445.

Spettus, I. L., Yehuda, R., Wong , C. M., Halligan, S., \& Seremetis, S. V. (2003). Childhood emotional abuse \& negect as predictors of psychological syptoms in women presenting t a primary care practice. Child Abuse \& Neglect. 2711), 1247-1258.

Spielberger, C. D. (1988). Professional manual for the State-Trait Anger Expression Inventory(STAXI, Research ed.),Tampa,FL: Psychological Assessment Resources, Inc.

Spielberger, C. D., Reheiser, E. C. \& Sydman, S. J. (1995). Measuring the experience, expression, and control of anger. Issues in Ped iatric Nursing, 18, 207-232.

Welburn, K., Coristine, M., Dagg, P., Pontefract, A., \& Jordan, S. (2002). The Schema Questionnaire-Short Form: Factor analysis and relationship between schemas and symptoms. Cognitive Theraphy and Research, 26, 519-530.

Wright, M. O., Crawford, E., \& Del Castillo, D. (2009). Childhood emotional maltreatment and later psychological distress among college students: The mediating role of maladaptive schemas. Child Abuse \& Negelect, 33, 59-68.

Wright, M. O., Crawford, E., \& Sebastian, K. (2007). Positive resolution of childhood sexual abuse experiences: The role of coping, benefit-finding and meaning-making. Journal of Family Violence, 22, 597-608.

Young, J. E. (1990). Cognitive therapy of personality disorders: A schema focused approach Sarasota, FL: Professional Resource Exchange, Inc.

Young, J. E. (1998). The Young Schema Questionnaire: Short Form Available in Electronic form at http://www.schematherapy.com/id55.html.

Young, J. E., Klosko. J. S., \& Weishaar, M. E. (2005). 심리도식치료 (권석만, 김진숙, 서수균, 주리애, 유성진, 이지영 역). 서울: 학지사. (원저 2003 출판)

Young, J. E., Weinberger, A. D., \& Beck, A. T. (2001). Cognitive therapy for depression. In D. Barlow (Ed.), Cinical handbook of psychological disorders. (3rd ed., pp. 264-308). NY: Guilford Press. 
* 논문접수 2014년 11월 4일 / 1차 심사 2014년 12월 12일 / 2차 심사 2015년 2월 1일 / 게재승인 2015년 3월 6일

* 조유경: 인천대학교 학생생활상담소

*E-mail: mailtoally@naver.com

* 이지연: 인천대학교 창의인재개발학과

*E-mail: becoming@incheon.ac.kr 


\title{
Childhood Emotional Trauma and Dysfunctional Anger Expression: Mediating Roles of Disconnection/Rejection Schemas and Psychological Maladjustment
}

\author{
Cho, Yukyeong* \\ Lee, Jeeyon ${ }^{\star \star}$
}

This study examined the effect of childhood emotional trauma, disconnection/rejection schemas and psychological maladjustment on dysfunctional anger expression which greatly influences other serious emotional maladjustment and interpersonal relations. The study conducted a survey with a total of 341 college students in Gyeonggi Province, Incheon and Seoul metropolitan city. From the collected data, which were processed with a statistic program, the study calculated a reliability coefficient Cronbach's a in order to verify the reliability level of each scale, and conducted a correlation analysis in order to examine the correlation among childhood emotional trauma, disconnection/rejection schemas, psychological maladjustment and dysfunctional anger expression. Finally, and the Structural Equation Modeling (SEM) approach was used. The results are as follows: the model that childhood emotional trauma influenced disconnection/rejection schemas and then influenced psychological maladjustment and finally influenced the dysfunctional anger expression was more appropriate than the partly mediating model. These results suggest that disconnection/rejection schemas and psychological maladjustment mediate the relation between childhood emotional trauma and dysfunctional anger expression. Therefore, in order to help patients to overcome their dysfunctional anger expression, counselors must consider their disconnection/rejection schemas and psychological maladjustment as well as their childhood emotional trauma. The limitations of current research were discussed.

Key words: childhood emotional trauma, disconnection/rejection schemas, psychological maladjustment, dysfunctional anger expression

\footnotetext{
* First author, Student counseling center, Incheon National University, mailtoally@naver.com
}

** Corresponding author, Associate Professor, Incheon National University, becoming@inu.ac.kr 
